\title{
An exploratory study on the mode and method of general education and training for general practice undergraduates: a narrative review
}

\author{
Rongyu Shang', Yutong Qin ${ }^{1}$, Fangfang Wang ${ }^{1}$, Peng Sun ${ }^{1}$, Lei Liu ${ }^{2}$, Chunji Huang ${ }^{3}$ \\ ${ }^{1}$ Department of Medical Education, School of Basic Medicine, Army Medical University, Chongqing, China; ${ }^{2}$ Academic Affairs Office, Army Medical \\ University, Chongqing, China; ${ }^{3}$ Army Medical University, Chongqing, China \\ Contributions: (I) Conception and design: C Huang, R Shang, Y Qin; (II) Administrative support: L Liu; (III) Provision of study materials or patients: \\ F Wang; (IV) Collection and assembly of data: P Sun; (V) Data analysis and interpretation: None; (VI) Manuscript writing: All authors; (VII) Final \\ approval of manuscript: All authors. \\ Correspondence to: Chunji Huang. Army Medical University, No. 30 Gaotanyanzheng Street, Shapingba District, Chongqing 400038, China. \\ Email: yxjy_wz@163.com.
}

Objective: To learn from the experience of foreign general practice education mode, and to exploratory study on the mode and method of general education and training for general practice undergraduates in China.

Background: The rise of general practice medicine addresses the lack of holistic attention to patients in specialist medicine. General practice education is an important means of training general practice skills, but the development of general practice education in China is not yet matured.

Methods: By using the method of comparative education, taking the United States, Australia, France and Britain as examples. This article makes a comparative analyzes the status of general practice education in foreign countries and discusses the development of undergraduate general practice education in China from four perspectives: national policy, teacher resources, curriculum system, and education training modes.

Conclusions: The four countries attach great importance to general practice education, with mature training methods, registered practice and continuing education. It is hoped that this article can establish and improve the policy system for the development of general subject teachers and optimize the inclusive, assessment and evaluation system of general practice teachers. In addition, more attention should be paid to general practice scientific research to create a teaching team with high standards, high quality, and high scientific research literacy and to form standardized scientific teaching methods that promote the development of general medicine education and training through high-quality teaching experiences. In addition, more attention should be paid to general practice scientific research to create a teaching team with high standards, high quality, and high scientific research literacy and to form standardized scientific teaching methods that promote the development of general medicine education and training through high-quality teaching experiences.

Keywords: General practice; medical undergraduates; general education; exploratory study

Submitted Nov 15, 2021. Accepted for publication Jan 07, 2022.

doi: $10.21037 / \mathrm{atm}-21-6635$

View this article at: https://dx.doi.org/10.21037/atm-21-6635 


\section{Introduction}

With the rapid development of modern medicine, various subtypes of medicine have become increasingly specialized and sophisticated. However, the strengthening of specialized medical expertise has created a situation in which specialists have limited exposure to multiple diseases. General practice medicine has arisen to compensate for this defect (1). The holistic approach of general practice medicine requires students to have a broader knowledge reserve, a better doctor-patient relationship, and a greater understanding of the local characteristics of medical services and experiences. General practice education and training is a teaching activity which apply biological-psychologicalsocial medical model to carry out the prevention, medical treatment, health care, rehabilitation, health education, family planning technical services as a whole. The target is cultivate talents who can be engaged in general practice in community and township health centers and other primary medical institutions. It is an important part and way to train general practitioners. Australia was one of the first countries in the world to establish General practice education and training. after many years of development, they thought of general practice training must allow registrars to develop into what they need to be to best meet the Future health care needs of their patients and their communities. GP training should focus on competency based training and also be based on defining the outcomes of training by competencies, Rather than by time served in a specific location. in addition, vertical integration model needs to be reinforced across undergraduate and postgraduate medical training, better horizontal links must be established with other craft groups. This will strengthen inter-professional learning to better meet the complex needs of many of patients and communities (2). In China, a hierarchical diagnosis and treatment system is still under construction. Grassroots medical resources are not able to meet the needs of the masses, and a lack of publicity surrounding general practitioners has led to inadequate public understanding of general practice services. As a result, the national policy, teacher construction, curriculum system and education training model of general practice education and training is not mature. The current general practitioner training in China cannot effectively meet the needs of the medical system. Therefore, the most urgent task is to promote the development of general practice medicine and the construction of a healthy China. General education in general practice is the foundation for improving the quantity and quality of general practice undergraduates (1). At present, the number of general practitioners in the country is insufficient, the quality of practitioners is not high, and the gap between practitioners and patients is very large. To achieve the goal of five general practitioners per 10,000 residents in 2030, 40,000 general practitioners need to be trained every year. This paper explores the question of how to train a group of general practitioners who can provide quality patient care based on the experience of general practice abroad while still pursuing a path of general practice education in line with China's national conditions and current medical reality.

We present the following article in accordance with the Narrative Review reporting checklist (available at https:// atm.amegroups.com/article/view/10.21037/atm-21-6635/rc).

\section{Methods}

From the perspective of accessibility and representativeness, this paper collected literatures related to the training modes and methods of general practice at home and abroad by visiting the home pages of some well-known medical colleges and universities and searching databases (CNKI, PubMed, VIP science and technology journals, Annual Reviews, Chinese Medical journals, etc.) and related academic websites. Focus on the analysis and summary of policy support, teacher resources, Curriculum systems, and educational modes.

\section{General practitioner education abroad}

General practice first arose in the United States in the 1960s. After 40 years of development and improvement, national institutions of higher education in countries such as the United States, Australia, France, Britain, and others have become the most representative teaching mode for general medicine (Table 1). In these countries, general medicine is a comprehensive clinical subject that blends biological medicine with the latest social and behavioral science research and the successful experience of general medical care. This has led to a methodology of basic medical services with its own characteristics, which has transformed medical teaching modes and improved the professional and service quality of medical staff.

\section{Policy support}

The Guidance on the Establishment of the General Practitioner 
Table 1 General medical education in foreign colleges and universities

\begin{tabular}{|c|c|c|c|c|c|}
\hline Nation & Teacher resources & The curriculum system & Training models & Teaching method & $\begin{array}{l}\text { General practice } \\
\text { departments or institutions }\end{array}$ \\
\hline USA & $\begin{array}{l}\text { Theoretical } \\
\text { teachers of } \\
\text { general practice; } \\
\text { clinical teachers; } \\
\text { community general } \\
\text { practitioners }\end{array}$ & $\begin{array}{l}\text { Rural environment } \\
\text { and practicing health } \\
\text { epidemiology, community } \\
\text { health services, community } \\
\text { clinical process, } \\
\text { biostatistics, and health } \\
\text { care management }\end{array}$ & $\begin{array}{l}4 \text { years of } \\
\text { undergraduate medical } \\
\text { education }+4 \text { years } \\
\text { of general practice } \\
\text { education }+3 \text { years } \\
\text { of resident training } \\
\text { (including } 1 \text { year of } \\
\text { community practice } \\
\text { training) }\end{array}$ & $\begin{array}{l}\text { CBL combined with } \\
\text { LBL teaching model. } \\
\text { PBL teaching method. } \\
\text { Digital teaching mode }\end{array}$ & $\begin{array}{l}\text { American Academy of } \\
\text { Family Physicians (AAFP) }\end{array}$ \\
\hline Australia & & $\begin{array}{l}\text { General practice } \\
\text { knowledge and skills, } \\
\text { communication and } \\
\text { doctor-patient relationship, } \\
\text { professional and ethical } \\
\text { roles, organization and } \\
\text { law, population health, } \\
\text { and general practice } \\
\text { background }\end{array}$ & $\begin{array}{l}\text { Apprenticeship } \\
\text { education ( } 6 \text { years of } \\
\text { undergraduate medical } \\
\text { education }+1 \text { year } \\
\text { residency }+1.5 \text {-year } \\
\text { apprenticeship) }\end{array}$ & $\begin{array}{l}\text { CBL combined with } \\
\text { LBL teaching model. } \\
\text { Apprenticeship } \\
\text { education. Clinical } \\
\text { practice teaching } \\
\text { method. PBL teaching } \\
\text { method }\end{array}$ & $\begin{array}{l}\text { Royal Australian College } \\
\text { of General Practitioners } \\
\text { (RACGP) }\end{array}$ \\
\hline France & & $\begin{array}{l}\text { General medicine and } \\
\text { its application fields, } \\
\text { practice and skills of } \\
\text { general medicine, the } \\
\text { current situation of general } \\
\text { medicine, diagnosis } \\
\text { strategy and evaluation, } \\
\text { and treatment of general } \\
\text { medicine }\end{array}$ & $\begin{array}{l}\text { Knockout education } \\
\text { mode ( } 6 \text { years of } \\
\text { medical education } \\
\text { consisting of bachelor's } \\
\text { degree and master's } \\
\text { degree }+2.5 \text { years } \\
\text { of general practice } \\
\text { residency training) }\end{array}$ & $\begin{array}{l}\text { Clinical practice } \\
\text { teaching method. } \\
\text { CBL combined with } \\
\text { LBL teaching model. } \\
\text { PBL teaching method. } \\
\text { Experiential teaching }\end{array}$ & $\begin{array}{l}\text { Le Troisieme Cycle des } \\
\text { Etudes de Medecine } \\
\text { (TCEM) }\end{array}$ \\
\hline
\end{tabular}

CBL, case-based learning; PBL, problem-based learning; LBL, lecture-based learning.

System issued by the State Council in 2011 identified an urgent need for the construction of a general practitioner system in China. Due to the relative lag in the development of general practice medicine in our country, there is a need to build a systematic and comprehensive general practitioner training system with Chinese characteristics so as to promote the construction of a graded diagnosis and treatment system (3). The Outline of the Healthy China 2030 Plan proposes to strengthen the construction of healthy human resources and meet the population's growing need for health services (4). In January 2018, the State Council issued the Opinions on Reforming and Improving the Incentive Mechanism for the Training and Use of General Practitioners, which again emphasized the importance of general practitioner education and training. General education is the core approach in the training of general practitioners, and the purpose of these policies is to support and guide the development of general practice education and training.

\section{Teacher resources}

The development of a general practice major is inseparable 
Table 2 Comparison of Chinese and Britain general practitioner medical education resources

\begin{tabular}{lllll}
\hline Country & $\begin{array}{l}\text { Composition of general } \\
\text { practice teachers }\end{array}$ & $\begin{array}{l}\text { Established general practice } \\
\text { departments or institutions }\end{array}$ & $\begin{array}{l}\text { Teacher training plan and } \\
\text { standardized textbook }\end{array}$ & Teaching characteristics \\
\hline Britain & $\begin{array}{l}\text { Theoretical teachers, clinical } \\
\text { teachers, and community } \\
\text { teachers }\end{array}$ & $100 \%$ & Yes & $\begin{array}{l}\text { Conform to the training } \\
\text { purpose of general } \\
\text { practitioners }\end{array}$ \\
& $\begin{array}{l}\text { University academics and } \\
\text { clinical teachers }\end{array}$ & $50 \%$ & No & $\begin{array}{l}\text { Most of them are part-time } \\
\text { teachers of general practice } \\
\text { and lack professionalism }\end{array}$ \\
\end{tabular}

from the training of general practitioners and the establishment of a general practice system. General practice teachers in China fall into three categories: theoretical teachers, clinical teachers, and community teachers. General practice education requires teachers from all three of these categories. For medical undergraduates, theoretical teachers of general medicine are the main source of training. Studies have shown that about $50 \%$ of the 128 medical colleges and universities in China have not established general practice departments or institutions $(5,6)$. In Britain, which has a long history of general practitioners providing the first point of contact, $100 \%$ of medical schools have had general practice departments since 2002 (7). The training of general practice teachers in Britain is regulated by authoritative general practice management institutions, general practice teaching standards, and certification institutions such as the British Royal College of General Practitioners (RCGP). The classification of teachers is as follows: theoretical teachers of general practice, who are mainly concentrated in higher medical colleges and universities; clinical teachers, consisting of general practitioners and specialists in general hospitals, as well as community general practitioners; and community teachers, consisting of general practitioners responsible for the teaching of community health service practice. At present, China lacks the necessary authoritative general practice management organizations, unified teacher training plans, and standardized teaching materials to build a contingent of general practice teachers. Due to the excessive emphasis on academic qualifications and professional titles, community doctors with rich clinical experience working at the grassroots level cannot enter the teaching team. Instead, general practice teachers are university academics and hospital specialists whose pedagogical and specialized knowledge runs counter to the training purposes of general practitioners listed in Table 2 (8). As general practice theory must be closely combined with clinical work, it is important to build a team of general practice teachers in line with regional characteristics of medical services.

\section{The curriculum system of general education}

Equal importance should be attached to general and professional education when cultivating general practice skills. A new curriculum system should combine humanities and social sciences, natural sciences, and biomedicine. In addition, the combination of basic medicine, clinical medicine, and preventive medicine facilitates the simultaneous development of knowledge and ability and improves the quality of general practice students (8). Currently, general education in general practice includes foundational courses, professional courses, skill modules (including clinical methods, communication skills, skill experiments, and early exposure to clinical practice), humanities and social sciences, public health and general practice courses, clinical probation, and clinical rotation practice. Although more than 40 textbooks related to general medicine have been published in China, there is a lack of targeted and standardized teaching materials, such as general practice communication skills and general practitioner teaching cases. Compare the number of learning materials specially formulated by the Royal Australian College of General Practitioners (RACGP) in Australia, including foundational texts such as General Practice (by John Murtagh) and the Treatment Guidelines series; guidelines for the implementation of drug compensation schemes; general internal medicine reference books (e.g., Harrison's Principles of Internal Medicine and Oxford Medical Textbooks); minor operation and management textbooks (e.g., Primary Care Physician's Surgery, Instructions and Diagrams for Minor Surgeries); other work-related books (e.g., Fractures and Foint Injuries, Pediatrics Textbook), and preventive medicine courses (e.g., Guidelines for Preventive Activities in General Practice (the Red book)). In China, the general practice education 
curriculum still requires improvement. Existing courses can be optimized by simplification, integration, reorganization, and addition to improve comprehensiveness and weaken the boundaries between disciplines. The curriculum as a whole can be enhanced by organically combining humanities and social sciences with medical specialties, strengthening the connections between integrated courses, and integrating basic medical courses with clinical courses. The further development of medical humanities courses and public health and general medicine courses would also help to achieve a more flexible, open, and complementary curriculum.

\section{Exploration of education and training models}

The content of general practice education includes clinical knowledge and skills (that is, medical knowledge), community general practice knowledge and skills (doctorpatient communication skills, teamwork, etc.), basic theory of general practice, and comprehensive qualityrelated knowledge (health education skills, communitybased prevention skills, and health care skills, etc.). Such skills are the foundation for becoming a people-oriented general practitioner in the future (9). According to some researchers, while many medical colleges and universities provide quality general practice education, they do not focus on promoting general practice as a lifelong career. Instead, general practice teachers are more focused on international conferences and clinical research than on inspiring undergraduates to pursue a career in general practice (10). Teachers should take the initiative in promoting general practice as a diversified and rewarding career by allowing medical students access to their daily work, so that they can better understand the methods of general practitioners and the basic functions of the primary health care system. The general practice teaching model focuses on the cultivation of a comprehensive health capacity, which emphasizes the mobilization of students' self-learning abilities so as to improve the teaching quality of general practice $(11,12)$. At present, the teaching methods of general practice education include the following nine models.

\section{Case-based learning (CBL) combined with lecture-based learning (LBL) teaching model}

CBL combined with LBL is a teaching mode that combines traditional lecture-based learning with non-traditional casebased learning. CBL methods are case-based, proactive, guided by teachers, and centered on medical students. Students learn to think and explore actively through exposure to real medical situations in the clinic so that they can master the skills necessary for clinical practice (13). LBL, a more traditional teaching mode, consists of instructors teaching the content of the syllabus in large classes. Studies have shown that CBL equips students with the knowledge and skills to solve clinical problems, to find the internal relationship between basic knowledge and clinical discipline knowledge, deepen the understanding and mastery of clinical knowledge, train positive thinking, prepare for clinical practice in advance, effectively combine theory and practice, and continue learning throughout their careers $(14,15)$. Compared with the more traditional LBL method, CBL allows students to actively participate in teamwork and master clinical skills and knowledge through problem solving. CBL combined with LBL can enhance the strengths of each method and provide more comprehensive and higher quality clinical training for general practice students.

\section{Experiential teaching}

Two British studies have shown that the key to motivating students is practical teaching involving contact with patients $(16,17)$. These studies suggest that early, high-quality, continuous, and real clinical practice experience can change negative stereotypes about general practice and encourage students to consider general practice as a future career. Clinical teaching provides authentic experiences and helps integrate theory with practice by allowing students the opportunity to take on clinical obligations, manage patients, and run their own clinics. The studies found that general practitioner internships were moderately related to career choice, thus emphasizing their value in general practice education.

\section{Autonomous learning}

General practice students are encouraged to study and think independently. Clinical experience is the basis of general practice education, and medical students rely on exposure to relevant experience to master relevant skills. However, due to the unpredictable complexity of the working environment, students are not guaranteed to encounter all skills required in future clinical work, so autonomous learning is also necessary. Treating autonomous learning as a training goal can help to produce general practitioners 


\section{Page 6 of 9}

who engage in lifelong learning and provide high-quality medical care (18).

\section{Near-peer teaching}

Near-peer teaching refers to the teaching of students by people who are close to them in experience but not at the same level. For example, medical schools encourage graduate mentors to provide graduate students with shortterm but regular opportunities to act as peer teachers for undergraduates. This allows graduate students to improve their teaching ability while accepting guidance and feedback. Utilizing the skills and energy of graduate students or seniors as near-peer teachers is a simple and effective means to improve the training of both undergraduate medical students and their near-peer teachers. Evidence suggests that most teachers are eager to improve their teaching, while undergraduate medical students attach great importance to the teaching of their peers $(19,20)$. Near-peer teaching can reduce the time pressure on teachers and help them to stay up-to-date, which can bring economic benefits to the business. Before assigning teaching roles to medical students, the students' abilities should first be assessed. Arranging longer internships and allowing student teachers to teach in areas of interest, specialty, or necessity is also important (21).

\section{Apprenticeship education}

Apprenticeship education is a traditional method of education with a long history and inheritance. This method is very suitable for the training of general practitioners, as it enables current general practitioners to train future general practitioners. The characteristics of apprenticeship education involve cultivating students' practical abilities, situating practical operation within theoretical study, and supporting students to master basic and comprehensive treatment in line with the personal conditions of patients. The teaching of this method mainly relies on experienced general practitioners who are already employed. As the closeness of the master-apprentice relationship directly affects the cultivation of students, the personal abilities of the teachers are critical to the success of this method. It is worth noting that in foreign countries, when implementing this general practitioner training model, the standards and requirements of teachers and training institutions are strictly formulated.

\section{Shang et al. General education and training for general practice}

\section{Clinical practice teaching method}

To achieve "early clinical, multi-clinical, and repeated clinical" social practice (22) and help general practice students improve their clinical practice abilities, medical schools should increase the weight of clinical practice teaching. A basis in clinical practice is required to provide medical students with professional, well-supervised, and instructive general practice rotation and to cultivate their abilities in four subscales of medical education: teaching, clinical skills, social support, and role autonomy (23).

Clinical practice can help cultivate the clinical abilities of general practice students, provide comparative environments and experiences, and improve the professional and personal growth of interns (24). In a study by Martin et al., $85.87 \%$ of undergraduates reported that clinical practice was a more suitable method of training. General practice education in college is mainly based on theoretical learning supplemented by practical learning (25). Therefore, clinical practice plays an important role in the learning of undergraduates. While participating in clinical practice, undergraduates are able to further enhance their consultation, diagnosis, and differential diagnosis abilities relating to common diseases through a variety of learning methods, such as standardized patients, scenario simulation, organizing case discussions, and so on.

\section{Mind mapping teaching method}

The mind mapping teaching method reflects the divergence and convergence of thinking and diverges from the subject terms to the surrounding level. Mind mapping is an effective mode for teaching medical specialties, as the professional knowledge required in general practice is diverse and complex. Mind maps allow students to connect different theoretical specialties and integrate scattered knowledge into a complete system, which can help them to think more clearly and deeply and to build up knowledge reserves. This can enhance students' interest in learning basic medical knowledge on their own. Depending on the skills of the teacher, the effective use of the mind mapping method can improve the quality of teaching for students $(26,27)$.

\section{PBL teaching method}

The problem-based learning (PBL) method is problembased, tutor-oriented, and student-centered. It advocates 
active learning and emphasizes the importance of problem solving and independent study. Chen et al. investigated the practical and theoretical benefits of the PBL teaching method in general practice education (28). Their results showed that the observation group scored higher than the control group, and the difference was statistically significant. This suggests that PBL can significantly improve academic performance. The PBL teaching method has the following advantages: (I) students' initiative and learning abilities are enhanced through the transformation of traditional "receptive" learning into "autonomous learning", e.g., turning simple listening into mutual communication and changing the process of simple acceptance, repetition, and memorization into the process of active discovery, analysis, summary, and presentation; (II) students are encouraged to develop knowledge acquisition habits such as consulting relevant literature and discussing and summarizing content with each other, which can strengthen memory and improve knowledge application.

\section{Digital teaching mode}

The digital teaching mode is a method of teaching in which students interact with teachers on a network-based platform. This mode allows students to allocate their study time according to their own situation, while also strengthening the interaction between teachers and students in colleges and universities. With the development of information technology, digital teaching has become the primary mode of general medicine theory teaching (29). Drawing on lessons from the current educational concept of "Internet +", network-based platforms can be used to facilitate the exchange of teaching resources and high-quality courses among colleges and universities; to formulate personalized learning plans and programs; to provide students with teaching resources such as clinical medical literature, works, case discussion videos, and lectures; and to help students develop rich knowledge reserves and optimize their knowledge structure. This mode of teaching promotes autonomous learning skills and encourages general practice undergraduates to become lifelong learners.

\section{Discussion}

General practice medicine can make up for the lack of holistic attention in clinical specialties, allowing medical undergraduates to focus on the "patients" themselves and to solve medical problems from the perspective of the whole patient (30). General education is the basis of general medicine education, many teaching models have been tried and adopted during this process, including basic professional and theoretical knowledge, effective clinical skills and practice, people-oriented care skills, and so on. This paper analyzes the models and methods of general education in general practice from four perspectives: policy support, teacher resources, curriculum systems, and educational modes. We suggest to improve the general practice education and training in the following aspects. Firstly, we increase financial support from the central and local governments for general practice trainees. Secondly, strengthen the construction of general practice training bases and training of full-time general practice teachers. Thirdly, establish a systematic curriculum system of general practice education and certification system of post-graduation continuing education. Fourthly, establish multi-level and progressive training mode of multi-path navigation. Fifthly, we should gradually improve the general practitioner training process assessment system and take other measures to improve the level of general practice education and training. With the continuous improvement of China's general practice education and training system and model, the service quality of general practitioners will continue to improve and meet the health needs of community residents. This paper explored the question of how to train a group of general practitioners who can provide quality patient care based on the experience of general practice abroad while still pursuing a path of general practice education in line with China's national conditions and current medical reality. It provides reference for the establishment and improvement of general practitioner training system and model in China.

\section{Acknowledgments}

Funding: This work was supported by Chongqing 2019 Higher Education Teaching Reform Research Project, Study on the value identity of non-military cadets in Military academies (No. 193370).

\section{Footnote}

Reporting Checklist: The authors have completed the Narrative Review reporting checklist. Available at https:// atm.amegroups.com/article/view/10.21037/atm-21-6635/rc

Conflicts of Interest: All authors have completed the 


\section{Page 8 of 9}

ICMJE uniform disclosure form (available at https://atm. amegroups.com/article/view/10.21037/atm-21-6635/coif). The authors have no conflicts of interest to declare.

Ethical Statement: The authors are accountable for all aspects of the work in ensuring that questions related to the accuracy or integrity of any part of the work are appropriately investigated and resolved.

Open Access Statement: This is an Open Access article distributed in accordance with the Creative Commons Attribution-NonCommercial-NoDerivs 4.0 International License (CC BY-NC-ND 4.0), which permits the noncommercial replication and distribution of the article with the strict proviso that no changes or edits are made and the original work is properly cited (including links to both the formal publication through the relevant DOI and the license). See: https://creativecommons.org/licenses/by-nc-nd/4.0/.

\section{References}

1. Feng Y, Yang JT, Wang YX, et al. Exploratory study on the training mode and method of general education of general practice for medical undergraduates. Contin Med Edu 2016;30:26-8.

2. Kidd MR, Beilby JJ, Farmer EA, et al. General practice education and training: past experiences, current issues and future challenges. Med J Aust 2011;194:S53-4.

3. Wang M, Wang JJ. The practice and experience of general practice education in Guangzhou Medical College. Chin Gen Pract 2005;8:702-3.

4. Dai T, Huang J, Ma XJ. The development of international general practitioner system: analysis of influencing factors and policy implications. Health Policy Res Chin 2015;8:1-7.

5. The outline of the Healthy China 2030 Plan. Chin Oncol 2019;28:724.

6. Liu XP, Lu XQ, Huang YF, et al. Problems and suggestions in general practice education and training in China. Contin Med Edu 2010;24:4-6.

7. Xie MR, Guo AM. General Practice Teacher's Textbook. Edited by Xie MR and Guo AM. Beijing, Beijing Science and Technology Press 2014; pp. 105-140.

8. Harding A, Rosenthal J, Al-Seaidy M, et al. Provision of medical student teaching in UK general practices: a cross-sectional questionnaire study. Br J Gen Pract 2015;65:e409-17.

9. Yang JH, Li GH. Research and practice of general practice
Shang et al. General education and training for general practice

resources training model. Health Soft Sci 2014;28:157-60.

10. Lu XQ, Du J, Wu Y, et al. To construct a long-term sustainable training system for general practitioners in China. Med Edu Manage 2020;pc6:231-8.

11. Matthews H. Medical schools and general practice. $\mathrm{Br} \mathrm{J}$ Gen Pract 2018;68:268.

12. Liu Y, Ping HE, Zhang DQ, et al. Integrated Curriculum System Development for Competency-oriented "3+2" Assistant General Practitioner Training Program. Chinese General Practice 2017;16-20.

13. Zhang DH, Xiu-Hua MA, Gang J, et al. Three-year review of Clinical Integrated Courses implementation for Beijing" $3+2$ "assistant general practitioners. Chinese Journal of General Practice 2017;29-36.

14. Yue JY, Chen J, Dou WG, et al. Using integrated problemand lecture-based learning teaching modes for imaging diagnosis education. BMC Med Educ 2018;18:183.

15. Yu Kai, Qi DJ, Liu B, et al. The influence of CBL combined with LBL on medical education environment in general practice teaching. Chin Contin Med Edu 2020;12:35-8.

16. Muthukrishnan SP, Chandran DS, Afreen N, et al. Planning, implementation, and evaluation of multicomponent, case-based learning for first-year Indian medical undergraduates. Adv Physiol Educ 2019;43:504-11.

17. Alberti H, Randles HL, Harding A, et al. Exposure of undergraduates to authentic GP teaching and subsequent entry to GP training: a quantitative study of UK medical schools. Br J Gen Pract 2017;67:e248-52.

18. Nicholson S, Hastings AM, McKinley RK. Influences on students' career decisions concerning general practice: a focus group study. Br J Gen Pract 2016;66:e768-75.

19. de Bever S, Bont J, Scherpbier N. Strengthening general practice by extending specialty training. Br J Gen Pract 2019;69:222-3.

20. Thampy H, Alberti H, Kirtchuk L, et al. Near peer teaching in general practice. Br J Gen Pract 2019;69:12-3.

21. van de Mortel TF, Silberberg PL, Ahern CM, et al. Supporting near-peer teaching in general practice: a national survey. BMC Med Educ 2016;16:143.

22. Silberberg P, Ahern C, van de Mortel TF. 'Learners as teachers' in general practice: stakeholders' views of the benefits and issues. Educ Prim Care 2013;24:410-7.

23. Zheng B, Lian D, Luo C, et al. Investigation and Analysis of the Self-protection Consciousness of Chinese Medical Students "Early Clinical, Multi Clinical, Repeated Clinical" Social Practice. World Latest Medicine 
Information 2018;33:56.

24. Anderson K, Haesler E, Stubbs A, et al. Comparing general practice and hospital rotations. Clin Teach 2015;12:8-13.

25. Martin AA, Laurence CO, Black LE, et al. General practice placements for pre-registration junior doctors: adding value to intern education and training. Med J Aust 2007;186:346-9.

26. Cabinur K, Zhou XH, Maifu BA, et al. Investigation and analysis of general practice cognition and community practice needs of general practice students in a third-class hospital in Xinjiang. Xinjiang Med 2020;50:703-6.

Cite this article as: Shang R, Qin Y, Wang F, Sun P, Liu L, Huang C. An exploratory study on the mode and method of general education and training for general practice undergraduates: a narrative review. Ann Transl Med 2022;10(2):111. doi: 10.21037/atm-21-6635
27. Yang J, Xie LC, Fu JY, et al. The application of mind mapping in the teaching of neurology at different stages. Contin Med Edu Chin 2020;12:32.

28. Chen J, Wang YF, Kou Y. Application effect of PBL teaching method in general practice teaching. Contin Med Edu 2019;33:27-8.

29. Li J, Cao C, Yang J, et al. Exploration of digital flipped classroom in general practice teaching. Contin Med Edu 2020;34:10-2.

30. Lv ZF, Guo AM. An introduction to general practice. Beijing: Higher Education Press 2010; pp. 1-34. 